\title{
高齢頻尿患者に括ける排尿記録分析：成人群との比較検討
}

名古屋大学医学部泌尿器科学教室 (主任 : 三宅弘治教授)

斉藤 政彦* 近藤 厚生 加藤 隆範

長谷川総一郎 加藤久美子 三宅 弘治

\section{ANALYSIS OF FREQUENCY VOLUME CHART IN ELDERLY PEOPLE WITH POLLAKISURIA}

Comparison between the Elderly and the Adult

\author{
Masahiko Saito, Atsuo Kondo, Takanori Kato, Soichiro Hasegawa, \\ Kumiko Kato and Koji Miyake \\ Department of Urology, Nagoya University School of Medicine
}

(Chief: Prof. K. Miyake)

Based on the frequency volume chart, 215 patients who complained of pollaksuria were clinically investigated. The subjects were divided into 2 groups: the elderly group was composed of 85 patients more than 65 years of age (mean of 72) and the adult group comprised 130 patients less than 64 years old (mean of 47). The elderly group was characterized by the fact that, during nighttime (after sleep), their urinary volume was larger, each voided volume was smaller and the number of voiding was greater than the other group. Clinical analysis of the causes of pollakisuria enabled us to subdivide them into 6 diagnostic categories. Among the elderly patients polyuria during sleep and unstable bladder were prevalent and among adult patients unstable bladder and over hydration were common. Medication was made in 80 patients $(37 \%)$, while $108(50 \%)$ needed neither medication nor surgery. It is stressed that the frequency volume chart is one of the important diagnostic tools to evaluate the cause of pollakisuria and to select appropriate treatment.

Key words: pollakisuria, elderly people, frequency volume chart

要旨: 頻尿患者215名を65歳以上の高齢者群（85例）と65歳未満の成人群（130例）に分類して, 排尿記 録を基にその排尿動態を比較検討した。 また，原因別に治療法を検討し，頻尿患者における排尿記録の 有用性について検討した。

1. 高龄者群は成人群に比較して就寝時尿量が有意に多く, 就寝時の 1 回排尿量が有意に少量であり, その結果, 就寝時の排尿回数は有意に頻回であった。

2. 頻尿の原因を分析し，215例を 6 つの診断に分類した。高龄者では就寝時多尿あるいは不安定膀胼 患者が, 成人群では不安定膀胱, 多飲多尿が主要な原因であった。

3. 治療法は原因に応じて選択した，抗コリン剤を主とする薬物を90例 (42\%) に処方した。放置また は飲水制限など特に治療を要しなかった症例は108例（50\%）であった。

4. 排尿記録は，頻尿を訴える患者の病態分析に極めて有用な診断補助法の一つである. キーワード：高齢者, 頻尿, 排尿記録

高齢者は成人に比較して頻尿を主訴に泌尿器科を受 診することが多い。これは高齢者では前立腺肥大症な ど下部尿路の通過障害, 中权神経系の機能低下, 加歯

* 現在, 愛知健康增進財団勤務
にともなら膀胖の機能異常などが高頻度に発生するた めと考兄られる ${ }^{122}$. また循環器機能, 腎機能が加秢と ともに低下するため就寝時の尿量が増加して夜間頻尿 を訴えることも多い3). 高齢者にとって頻尿, 特に就寝 時の頻尿は睡眠不足につながり深核な問題である。

我々は以前より, 頻尿患者のスクリーニング検査と 
して排尿記録（frequency volume chart）を患者に記 載させている.排尿記録は1974年に Torrens が治療に 対する効果判定に用いたのが最初である4)。しかしそ の有用性や，それから得られた結果を分析した報告は 少ない，今回はこの排尿記録に基づき器質的病変を合 併しない頻尿患者215例を対象に, 65歳以上の高龄者群 と65歳未満の成人群とに分類し，1 日の尿量， 1 回の 排尿量および排尿回数を覚醒時と就寝時に分けて比較 検討を行なった。また，排尿記録の結果に基づいた診 断別治療法を検討し，頻尿患者に抢ける排尿記録の有 用性について検討した。

\section{症例と方法}

症例は頻尿（就寝時頻尿を含む）を主訴に，1987年 3 月より1990年 8 月までの 3 年 6 カ月間に名古屋大学 泌尿器科を受診した 215 例（平均年齢50.7歳, 男66例, 女149例)である。下部尿路機能に影響をおよぼす器質 的病変(前立腺肥大症, 神経因性膀胱など)，1日の尿 量が増大する器質的疾患（重度の糖尿病, 尿崩症, 慢 性腎不全）を有した症例は検討より除外した。厚生省 の基準にしたがい65歳以上を高齢者とした，高齢者群 は65歳から84歳の 85 例(平均年齢72.2歳：男33，女52） からなり，成人群は16歳から64歳の 130 例（平均年齢 46.9歳：男33，女97）である. 主訴と合併症を表 1 に 記載した。

受診時に，排尿動態に関連すると思われた薬剤を内 服していた患者は28例であった(表 2 )。これらの薬剤
表 1 患者の主訴と合併症（“延べ人数）

\begin{tabular}{ll|l}
\hline \multicolumn{2}{c|}{ 高齢者(65歳以上) } & 成人(65歳未満) \\
\hline 主訴： & & \\
頻尿 & $52(61 \%)$ & $96(74 \%)$ \\
就容時頻尿 & 15 & $7)$ \\
頻尿+尿失禁 & $28(33 \%)$ & $31(24 \%)$ \\
頻尿+排尿困難 & $5(6 \%)$ & $3(2 \%)$ \\
合併症* & & \\
高血圧 & 15 & 6 \\
脳動脈硬化 & 8 & 1 \\
軽度の糖尿病 & 6 & 3 \\
心疾患 & 4 & 2 \\
軽度精神疾患 & 3 & 4 \\
その他 & 8 & 10 \\
\hline
\end{tabular}

表 2 当科受診時内服薬（排尿, 尿量に関係するもの）

\begin{tabular}{|c|c|c|}
\hline & 高龄者群 & 成 人群 \\
\hline 抗コリン剤 & 5 & 4 \\
\hline 塩酸フラボキサート & 6 & 1 \\
\hline 利尿剂 & 4 & 1 \\
\hline 塩酸プラゾシン & 1 & 2 \\
\hline 臭化ジチグミン & 2 & 1 \\
\hline 三環系抗慱剤 & 2 & 1 \\
\hline
\end{tabular}

は内服を継続した状態で排尿記録を記載させた。

排尿記録は患者に $2 \sim 4$ 枚の排尿記録用紙（因 1) と $400 \mathrm{ml}$ の蛹引きの計量紙コップ(Daicup, 日昭産業) を手渡し，覚醒している時間帯（昼間）と就寝してい

図 1 名古屋大学泌尿器科で使用している排尿記録用紙

排厡記録

排厡回数排尿量尿失奨の記録

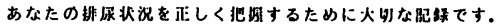

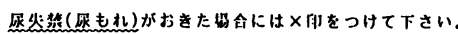

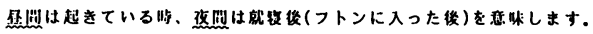

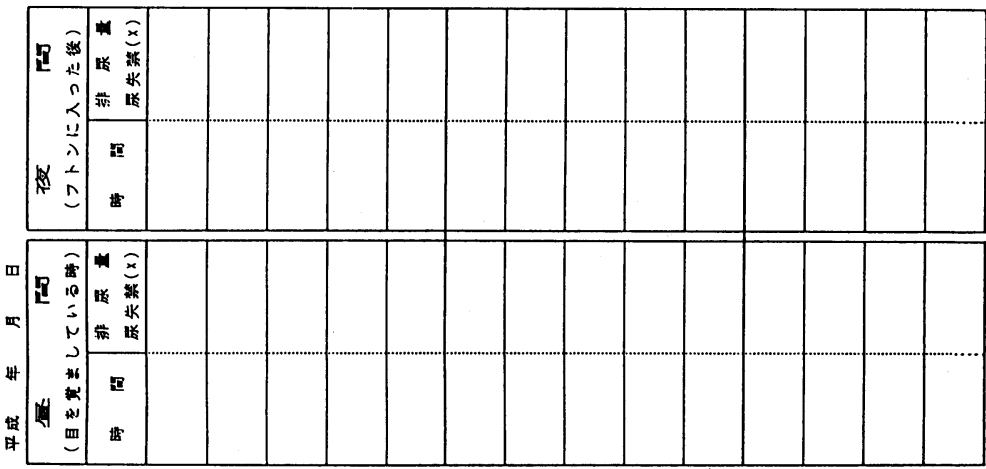


る時間帯（夜間）に分けてそれぞれにおける排尿時間 と排尿量を朝起床時から翌朝起床時までの 24 時間にわ たり 1 枚の記録用紙に記録させた。尚，就寝時間は眠 りについてからの時間とし，この点については排尿記 録の記載方法を説明する際に明確にし，さらに評価す る際に再確認した。排尿記録より評価可能のデータを 各個人から抽出し, 複数回実施した場合にはその平均 を各患者個人のデータとした．抽出データ回数は 1 回 が21例， 2 回が141例， 3 回以上が53例であった。排尿 記録より総尿量 (24時間, 覚醒時, 就寝時)，1 回排尿 量 (24時間, 覚醒時, 就寝時), 排尿回数 (24時間, 覚 醒時, 就寝時)を計算した。但し, 就寝時の排尿回数 が 0 回の症例が高齢者群で 4 例, 成人群で 25 例あった. 就寝時の尿量, 就寝時の 1 回排尿量はこれらの症例を 除外して計算した。就寝前の排尿時間と翌朝起床時の 排尿時間の間を睡眠時間として算出した。その結果, 高龄者群の睡眠時間は $8.64 \pm 0.96$ 時間, 成人群のそれ は8.46士1.09時間で有意差は認めなかった。膀胱内圧 測定は34例 (16\%) に，また尿流量測定は161例 (75\%) に対して施行した。

排尿記録, 病歴, 尿流量測定, 現症などに基づいて, 頻尿の原因を推測し，次の 6 つの診断に分類した，1） 就寝時多尿：原則として 1 日の全尿量の $35 \%$ 以上が就 寝時に排尿される症例. 2) 不安定膀胱：覚醒時, 就寝 時ともに 1 回排尿量が減少し, 尿意切迫感または切迫 性尿失禁を合併する症例. 3）多飲多尿：原則として 1 日の尿量が女性で $1800 \mathrm{ml}$, 男性で $2200 \mathrm{ml}$ 以上の症例. 4）心因性頻尿：昼間のみ 1 回排尿量の減少を訴える が, 就畠時, あるいは朝一番の排尿量が正常の症例. 5）正常排尿：排尿記録より 1 日の尿量, 1 回排尿量, 排尿回数などが正常範囲内と判断された症例. 6) その 他：排尿記録，病歴などより上記の 5 つに分類不能な 症例.さらに各診断ごとの排尿動態と治療法について も検討を行なった。

\section{結 果}

排尿記録に基づいて算出したパラメーターを表 3 に 示した。高齢者群と成人群の 24 時間尿量はほぼ同量で

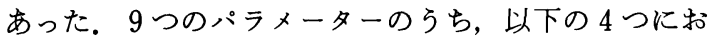
いて両群間で有意差を認めた。すなわち高齢者群では 成人群に比較して就寝時尿量が有意に多く，一方，覚 醒時尿量は少なかった，さらに就寝時の排尿回数は高 齢者群で多く, 就寝時の 1 回排尿量は成人群の方が多 かった。また高龄者，成人いずれも就寝時の 1 回排尿 量は覚醒時のそれに比較して有意に増大していた。排 尿記録に基づいた診断を表 4 に示した．高龄者群では 就寝時多尿, 不安定膀胱の割合が高く, 成人群では不 安定膀胱と多飲多尿が多かった。表 5 は診断別に，そ の排尿動態を分析したものである．下線を付した数値 が各診断の特徴を適切に示している。

診断別の治療法を表 6 に示した。主な治療法として

表 3 排尿記録よりのデータ分析：高龆者と成人の比較

\begin{tabular}{|c|c|c|c|c|}
\hline & & $\underset{(\text { mean }}{\text { 尿 }} \mathrm{SD}_{\mathrm{ml}}$ & $\begin{array}{c}\text { 排尿回数 } \\
\text { (mean } \\
\text { (mD) }\end{array}$ & $\begin{array}{c}1 \text { 回排原量 } \\
(\text { mean } \pm \text { SD }\end{array}$ \\
\hline \multirow{2}{*}{ 24時間 } & 高龄者 & $1543 \pm 615$ & $11.4 \pm 4.0$ & $145 \pm 58$ \\
\hline & 成人 & $1550 \pm 610$ & $11.1 \pm 5.4$ & $162 \pm 95$ \\
\hline \multirow{2}{*}{ 覚醒時 } & 高榆者 & $1086 \pm 550$ & $8.6 \pm 3.2$ & $134 \pm 59$ \\
\hline & 成人 & $1247 \pm 542$ & $9.5 \pm 3.4$ & $154 \pm 96$ \\
\hline \multirow{2}{*}{ 就寝時 } & 高齢者 & $490 \pm 2857$ & $2.8 \pm 1.77$ & $181 \pm 84$ \\
\hline & 成人 & $368 \pm 254$ & $1.6 \pm 1.6^{*}$ & $242 \pm 121$ \\
\hline
\end{tabular}

$* \mathrm{p}<0.05,{ }^{* *}: \mathrm{p}<0.01$

表 4 診断（頻尿の原因）

\begin{tabular}{l|c|c}
\hline \multicolumn{1}{c|}{ 診 } & 高柃者群(85例) & 成人群(130例) \\
\hline 就寝時多尿 & $31(37 \%)$ & $19(15 \%)$ \\
不安定膀胱 & $29(34 \%)$ & $36(28 \%)$ \\
多飲多尿 & $12(14 \%)$ & $30(23 \%)$ \\
心因性頻尿 & $2(2 \%)$ & $20(15 \%)$ \\
正常排尿 & $6(7 \%)$ & $14(10 \%)$ \\
その他 & $5(6 \%)$ & $11(9 \%)$ \\
\hline
\end{tabular}

表 5 各診断別パラメターの平均値

\begin{tabular}{|c|c|c|c|c|c|c|c|}
\hline & \multicolumn{3}{|c|}{ 総尿量 $(\mathrm{ml})$} & \multicolumn{2}{|c|}{1 回排尿量 (ml) } & \multicolumn{2}{|c|}{ 排尿回数 } \\
\hline & 24時間 & 覚醒時 & 就寝時 & 覚醒時 & 就寝時 & 覚醒時 & 就寝时 \\
\hline 就寝時多尿 & 1587 & 927 & $\underline{660}$ & 129 & $\underline{214}$ & 7.3 & 3.8 \\
\hline 不安定膀肤 & $\underline{1081}$ & 784 & 279 & $\underline{89}$ & $\underline{98}$ & 8.8 & $\underline{3.0}$ \\
\hline 多领多尿 & 2387 & $\underline{1998}$ & 392 & 223 & 297 & 9.3 & 1.6 \\
\hline 心因性頻尿 & 1351 & 1175 & 180 & $\underline{84}$ & $\underline{176}$ & $\underline{14.7}$ & $\underline{1.2}$ \\
\hline 正常排尿 & 1272 & 1149 & 234 & 179 & 230 & 6.8 & $\underline{0.5}$ \\
\hline
\end{tabular}


表 6 頻尿患者の診断別治療法

\begin{tabular}{|c|c|c|c|c|c|c|}
\hline & $\begin{array}{c}\text { 不安定膀胱 } \\
\mathrm{n}=65\end{array}$ & $\begin{array}{c}\text { 就寝時多尿 } \\
\mathrm{n}=50\end{array}$ & 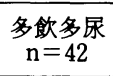 & $\begin{array}{c}\text { 心因性頻尿 } \\
\mathrm{n}=22\end{array}$ & $\begin{array}{c}\text { 正常排尿 } \\
\mathrm{n}=20\end{array}$ & $\begin{array}{c}\text { その他 } \\
\mathrm{n}=16\end{array}$ \\
\hline 抗コリン剂 & 44 & 22 & - & - & - & 10 \\
\hline 経過観察 & 6 & 18 & - & 17 & 20 & 5 \\
\hline 電気刺激 (FES) & 4 & - & - & - & - & - \\
\hline イミプラミン & 4 & 2 & - & - & - & - \\
\hline エストロジェン & 4 & - & - & - & - & - \\
\hline 领水制限 & - & - & 42 & - & - & - \\
\hline 利尿剤 & - & 4 & - & - & - & - \\
\hline 心理分析 & - & - & - & 4 & - & - \\
\hline その他 & 3 & 4 & - & 1 & - & 1 \\
\hline
\end{tabular}

不安定膀胼には，抗コリン剂が投与されていた。就寝 時多尿には抗コリン剤の投与と経過観察が主に実施さ れていた。多飲多尿と判明した症例には飲水制限が指 導されていた。因性頻尿, 正常排尿の症例に対して は経過観察がなされていた，全体として抗コリン剤を 主とする薬物は90例 (42\%) に処方され, 経過観察ま たは飲水制限など特に治療を要しなかった症例は 108 例 (50\%) であった。

\section{考察}

高齢者では成人に比較して頻尿を主訴に泌尿器科を 受診する患者が多い，頻尿は主に前立腺肥大症などの 下部尿路の通過障害や，脳血管障害，糖尿病などの神 経因性膀胱が原因で発生する。一方，このような器質 的疾患以外にも高齢者では不安定膀脂の発生頻度が高 く ${ }^{6)}$, さらに循環器機能や腎機能の低下による就寝時 多尿も頻尿の原因として重要である ${ }^{3)}$. また生活習慣 としての多飲も頻尿の原因となり，我々の分析によれ ば高齢者の 12 例 (14\%), 成人群の 30 例 (23\%) がこれ に相当した。

頻尿とは排尿回数が増加した状態であり，排尿回数 は強い尿意を感じる機能的膀胱容量と，24時間に産成

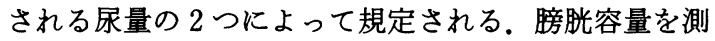
定する方法として膀腅内圧測定があるが，煩雑で，か つ侵襲的である。自然な 1 回排尿量，すなわち機能的 膀胱容量を非侵襲的に知るには排尿記録が優れてい る. 今回の排尿記録の分析から高齢者の頻尿患者の特 徵は，(1) 就蔓時の尿量の増大と，(2) 就寝時におけ る 1 回排尿量の減少が認められ, その結果,（3）就寝 時の排尿回数が増加して頻尿となっていることが判明 した（表 3 ）。就蔓時の頻尿は睡眼不足の原因となり， 患者ばかりでなく，家族にとっても深刻な問題となる。 Barker and Mitteness ${ }^{5}$ は老人ホームに入所している
高齢者を対象に夜間頻尿に関して検討した。彼らは尿 禁制患者の $64 \%$ ，尿失禁患者の $93 \%$ が夜間尿を有し， これが睡眠不足などの重大な問題をひきおこしている と指摘している. 今回の対象症例の内, 高齢者で就寝 時頻尿を主訴に受診した人は15例と少ない。しかし， 排尿記録を実際に検討してみると，不安定膀胱と，就 寝時多尿の症例では就寝時の排尿回数が明らかに増加 していた（表 4，5）.

\section{1. 就蔓時尿量の増大}

高齢者において, 就寝時の尿量が增大する主な要因 は以下のものが考兄られる。

\section{a. ホルモン環境の変化}

正常人の尿産成には明確な日内変動（circadian rhythm)が認められ，これは主にバソプレッシンやレニ ンーアンギオテンシンーアルドステロン系といったホ ルモンにより司られている77. 正常人の血中バンプ レッシンは，昼間に低く夜間に高いとい5日内変動が 証明されて打り，夜間のバンプレッシン分泌の増大に より夜間尿の産成が抑制されている7). 高龄者ではバ ソプレッシン分泌の反応性が低下して打り8)，これが 就寝時の多尿に関連している可能性が示唆される。一 方, 血浆レニンも正常人では著しい日内变動を示す7). 高齢者では血浆レニンは低下傾向を示し，それにとも ない血中のアルドステロンも低下するとされてい る9).

\section{b. 腎機能の低下}

腎機能も加龄にともない変化する。腎動脈の硬化に より腎実質の萎縮が発生する ${ }^{10)}$ 。また糸球体汇過率 (GFR) p有効腎血流量 (RPF) は20歳以後年龄ととも に直線的に低下寸るとされており ${ }^{11}$, 希釈力, 濃縮力な どの尿細管機能も高㱓者では低下する ${ }^{12)}$. 特に遠位尿 細管機能である尿濃縮力の低下は著明である ${ }^{12)}$. 


\section{c. 循環器系の機能低下}

今回の検討症例でも，高血圧，心臟病の合併が高齢 者群で多かった，循環器系の予備能力が低下した状態 では，覚醒活動時は，おもに筋肉や消化管に血流が分 配されるが，就寝時，安静臥床により腎血流が増大す る。その結果, 腎に打ける尿産生が増大し, 就寝時の 尿量が増える. 従って循環器系の機能が低下している 高齢者では，昼間に多く夜間に少ないという正常な尿 産生パターンが崩れやすい.

\section{d. 自律神経系の機能低下}

高齢者では自律神経系の機能，特に環境変化に対す る調節機能が低下するとされている ${ }^{13)}$. 自律神経系の 機能の中でも血圧調節機能の低下は前述の腎機能や循 環器系の機能に影響を及ぼし，就寝時尿量の増大に関 与することが考えられる．また高齢者では体温調節機 能の一つである発汗機能も低下して拈り，これは尿量 に直接影響を及ぼすと考えられる。

\section{2. 就寝時 1 回排尿量の減少}

高齢者, 成人いずれも就寝時の 1 回排尿量は覚醒時 のそれに比較して有意に増大していた。昼間の排尿は 個人の排尿習慣や周囲の状況に影響されやすく，特に 頻尿患者では早めにトイレに行く習慣がある。一方, 就寝時は無意識状態であり，周囲の状況に影響される ことなく, 強い尿意により初めて覚醒するため，1回 排尿量が覚醒時に比較して大きいと考兄られる。高秢 者では成人に比較して就寝時の 1 回排尿量が有意に低 容量であり，また夜間に排尿しない症例も若年者に比 較して低率であった。これは不安定膀胱の発生率が高 齢者で高いためと考えられた。不安定膀脱に罹患する 患者は膀胼の過活動性から頻尿や切迫性尿失禁を訴 え，70歳以上では全人口の $20 ３ 0 \%$ に達するとされて いる ${ }^{6)}$. 今回の分析では, 高齢者の $34 \%$ が不安定膀胱と 診断された。本疾患の確定診断は，顕性神経疾患の除 外と膀胱内圧測定で無抑制収縮を証明することであ る $^{14)}$. しかし日常診療において, 頻尿患者全例に膀胼内 圧測定を実施することは容易でなく，かつ望ましくな い，そこで，排尿記録により排尿動態を知り，昼夜を 問わず 1 回排尿量が減少し，尿意切迫感をたは切迫性 尿失禁をともなっている場合には本症と診断してょ い.

\section{3. 治療}

就寝時尿量の増大に対する治療は, 循環器機能, 腎 機能の改善が見込める症例には内科的なアプローチを 奖める，朝一番に利尿剂を内服させて体内の水分を絞
り，その分夜間の循環器系の負担を減らし，尿量を減 らすのも 1 つの方法である，但し，電解質異常などの 副作用の発生や, 循環動態の変化が生じる恐れがあり, 安易に長期間投与してはならない，膀胱容量が充分に 大きければ水分摄取の制限により全体の尿量を減少さ せる，夜間の排尿回数がそれほど多くない場合にはそ のまま経過観察とする。

不安定膀脱に対する治療は，膀胱の過活動性を抑え て膀脱容量を増大させる抗コリン剂が有効である，経 皮的電気刺激（FES）は副作用がなく，不安定膀脱に 対して有効とされている15). しかし，その有効率は論文 で発表されているほど高くなく，我々の経験では $20 \%$ 程度である。エストロジェン製剤は，閉経後の女性で 萎縮性臸尿道炎に罹患しているような患者には有効な 治療法である。

多领多尿に基づく頻尿は，排尿記録を見せて 1 日の 尿量が標準尿量に比較して絶対的に多いことを説明す る。一般にこの群の患者は，生活習慣に根ざしている 水分の過剩摂取を認識していない，頻尿が生活上問題 があれば飲水制限をさせるが，そらでなければ放置と する.

心因性頻尿に対しては，排尿記録を見せて昼間のみ に頻尿が存在し，昼間の 1 回排尿量が夜間に比較して 少ないために発生することを説明する，次にトイレ， 尿意，排尿などに過剰な関心を払わないように注意す る。心理分析を依頼することもある．患者の多くはす でにいくつかの医療機関を経由して打り，一般に難治 性である。

頻尿患者の中には他人と比較して排尿回数が多いと か，あるいは以前に比較して排尿回数が増加したため に治療を求めてくる患者もいる。このような中には排 尿記録をつけさせると，排尿回数，1回排尿量，24時 間尿量などいずれる客観的に正常範囲と判明する症例 も多い。このような症例は排尿記録をつけることで本 人も納得し，当然治療は不用である。

頻尿患者に対する治療の基本原則はまずその原因を 究明することである．頻尿を訴える患者にむやみに抗 コリン剂を処方したり，水分摄取を制限したりするこ とは厳に慎まなければならない，高齢者の相対人口比 が急激に増加する本邦では高龄者の特徵を考虑にい れ，可及的に非侵襲性の検査が必要となる。この観点 からすると排尿記録は極めて理想的な検査方法であ る. 今回の分析より治療法として薬物を要したのはわ ずかに $42 \%$ にすぎず，50\%の症例では経過観察または 
领水制限のみで対処することができた。

結語

頻尿患者215名を65歳以上の高齢者群 (85例) と65歳 未満の成人群 $(130$ 例) に分類して，排尿記録を基にそ の排尿動態を比較検討した。

1. 高齢者群は成人群に比較して就寝時尿量が有意 に多く, 就畠時の 1 回排尿量が有意に少量であり, そ の結果, 就寝時の排尿回数は有意に頻回であった.

2. 頻尿の原因を分析し，215例を $6 つ$ の診断に分類 した.

3. 治療法は原因に応じて選択した。抗コリン剂を主 とする薬物を90名（42\%）に処方した。108例（50\%） は経過観察または飲水制限などで対処できた。

4. 排尿記録は頻尿を訴兄る患者の病態分析に極め て有用な診断補助法の一つである.

\section{文献}

1) Dam, A.M., Hebjorn, S. and Hald, T.: Neurological disorder and detrusor hyperreflexia. Acta Neurol. Scand., 54, 415-422, 1976.

2）斎藤政彦, 後藤百万, 加藤久美子, 近藤厚生：高龄 ラットに拈ける薬理学的実験. 第 1 報。Acetylcholine, Norepinephrine, Isoproterenol に対する 反応。日泌尿会誌，81，25-30，1990。

3）斉藤政彦, 近藤厚生：高龄者の夜間頻尿. 現代医 学, 37, 113-117, 1987.

4) Torrens, M. : Patient assessment. in Urodynamics, Abrams, P., Feneley, R. and Torrens, M., 1st ed., p. 15-20, Springer-Verlag, New York, 1983.

5) Barker, J.C. and Mitteness, L.S.: Nocturia in the elderly. Gerontologist, 28, 99-104, 1988.

6) Turner-Warwick, R., Whiteside, C.G., Arnold, E.P., Bates, C.P., Worth, P.H.L., Milroy, E.G.J., Webster, J.R. and Weir, J.: A urodyanamic view of prostatic obstruction and the results of prostatectomy. Br. J. Urol., 45, 631-645, 1973.

7）吉田 尚：尿排泄のリズムと内分泌機構. 蛋白 質・核酸・醭素，27，227-232，1982.

8) Rowe, J.W. and Robertson, G.L.: Age-related failure of volume-pressure mediated vasopres$\sin$ (AVP) release in man. Kidney Int., 14, 660, 1978.

9) Weidman, P., Myttenare-Burszeiten, S.D., Maxwell, M.H. and Lima, J.D. : Effect of aging on plasma renin and aldosterone in normal man. Kidney Int., 8, 325-333, 1975.

10) Friedman, S.A., Reizner, A.E., Rosen, H., Solomon, N.A. and Sy, W. : Functional defects in the aging kidney. Ann. Intern. Med., 76, 41-45, 1972.

11) Davis, D.F. and Shock, N.W.: Age changes in glommerular filtration rate, effective renal plasma flow, and tubular excretory capacity in adult males. J. Clin. Invest., 29, 496-507, 1950.

12) Dontas, A.S., Maketops, S.G. and Papnayatou, P.: Mechanism of renal tubular defects in old age. Prostgrad. Med. J., 48, 295-303, 1972.

13）祖父江逸郎：高齢者の神経機能。高齢者の生活と 長寿科学, p. 59-69, 第 1 版, 長寿科学振興材団, 東京, 1991.

14) International Continence Society on Standardization of terminology of lower urinary tract function. Br. J. Urol., 53, 333-335, 1981.

15) Fall, M.: Electrical pelvic floor stimulation for the control of detrusor instability. Neurourol. Urodyn., 4, 329-335, 1985.

16) Walter, S., Wolf, H., Barbelo, H. and Jensen, $H$. $\mathrm{K}$.: Urinary incontinece in postmenopausal women treated with estrogen; a double-blind clinical trial. Urol. Int., 33, 135-143, 1978.

（1991年 6 月 12 日受理） 